\title{
Fasting Serum Insulin Level Among Overweight and Obese School Children
}

\author{
Mahmudul Haque 1* $^{*}$ \\ Md Jahangir Khan \\ Mahmood A Chowdhury 2 \\ Md Saifuddin Khaled ${ }^{3}$ \\ Prasun Barua'
}

\author{
Department of Biochemistry \\ Chittagong Medical College \\ Chittagong, Bangladesh. \\ ${ }^{2}$ Department of Pediatrics \\ Chattagram Maa Shishu-O-General Hospital \\ Chittagong, Bangladesh. \\ ${ }^{3}$ Department of Pediatric Pulmonology \\ National Institute of Disease of \\ Chest and Hospital (NIDCH), \\ Dhaka, Bangladesh.
}

\begin{abstract}
Background: The rising prevalence of obesity in developing countries is largely due to rapid urbanization and mechanization which has led to reduction in the energy expenditure. It is accompanied along with an increase in energy intake due to increased purchasing power and availability of high fat, energy dense fast food. A high prevalence of obesity in children can be attributed to the lack of knowledge about adverse effects of unhealthy nutrition in urban school children in Bangladesh. So there is a need to identify overweight and obesity as one of the risk factors leading to condition of metabolic syndrome and or central obesity and give baseline information to approach for its prevention at childhood with the assistance from continuation of medical research as early as possible. Methods: This was a case control study. A total of 100 subjects were included in this study. Among them 50 were considered as cases (Whose BMI was $>85$ th percentile) and 50 were considered as controls (Whose BMI was $>5$ th percentile to 84th percentile). BMI were calculated by standard protocol used for children. Children suffering from DM, renal diseases and other endocrine diseases were excluded. Serum insulin, blood glucose, total cholesterol, LDL-C, HDL-C and TG were measured in all samples in fasting state. Insulin resistance was calculated by HOMA-IR value. Results: Result showed that serum insulin and HOMA-IR values were significantly higher in cases (Overweight and obese children) than in controls of same age and $\operatorname{sex}(\mathrm{p}=<0.001)$. Result also showed that there were positive correlation among Total Cholesterol $(\mathrm{p}=<0.001)$, LDL-C $(\mathrm{p}=<0.001), \mathrm{TG}(\mathrm{p}=<0.001)$ and HOMA-IR value. Conclusion: We found that insulin resistance was strongly associated with metabolic syndrome and its components.
\end{abstract}

Key words: Fasting serum insulin; Overweight and obese; School children.

\section{INTRODUCTION}

The prevalence of chronic or non-communicable disease is escalating much more rapidly in developing countries than that in industrialized countries. According to World Health Organization estimates, by the year 2020, non-communicable diseases will account for approximately three quarters of all deaths in the developing world ${ }^{1}$. Obesity is a major risk factor for chronic diseases and plays a central role in the "insulin resistance" or "metabolic syndrome" which includes hyperinsulinemia, hypertension, hyperlipidemia, type 2 diabetes mellitus, and an increased risk of atherosclerotic cardiovascular disease ${ }^{2,3}$. The metabolic syndrome is a common pathophysiologic condition with implications for the development of many chronic diseases. Obesity beginning in childhood often precedes the hyperinsulinemic state and tends to persist into adulthood ${ }^{4,5}$. Identifying individuals with increased fasting insulin level is crucial as it increases the risk of developing type 2 diabetes by fivefold and CVD by two-fold along with consequences of metabolic syndrome ${ }^{6}$. 


\section{MATERIALS AND METHOD}

The study was a case control study which conducted in the Department of Biochemistry, Chittagong Medical College from July 2014 to June 2015.

Proper permission was taken for this study from the Ethical Review Committee of Chittagong Medical College, Chittagong, Bangladesh, to determine the HOMA (Homestatic Model Assessment) IR value and lipid profile among the overweight $\&$ obese school going children.

The children of different schools of Chittagong City fulfilling the enrollment criteria were included in this study.

Laboratory parameter: Chemiluminescence enzyme immunometric assay for the quantitative determination of human insulin concentrations in human serum by Siemens immulite 2000 systems. Total Cholesterol (TC) and Triglyceride (TG), HDL-C were estimated by enzymatic method. The glucose oxidase-peroxidase method was used for measurements of fasting plasma glucose. All measurements were analyzed in automated analyzer (Siemens Germany). Low-Density Lipoprotein-Cholesterol (LDL-C) was calculated by the Friedewald formula. (LDL = Total Cholesterol - HDL $1 / 5 \mathrm{TG}) \mathrm{mg} / \mathrm{dl}^{7}$. Insulin resistance was calculated by using the HOMA model [HOMA-IR $=$ fasting insulin $(\mathrm{IU} / \mathrm{mL}) \times$ fasting glucose $(\mathrm{mmol} / \mathrm{L}) / 22.5]$. HOMA-IR cut off is $>2.5^{8}$. A given fasting normal value of serum insulin $=5$ to $15 \mathrm{IU} / \mathrm{mL}$ (According to American Diabetic Federation) and fasting plasma glucose $=3.9$ to $6.1 \mathrm{mmol} / \mathrm{L}$.

Body Mass Index (BMI): Body height and weight was measured according to a standardized protocol with participants standing without shoes and heavy outer garments. Body Mass Index (BMI) was calculated as weight in kilograms divided by the square of the height in meter $\left(\mathrm{kg} / \mathrm{m}^{2}\right)$.

\section{RESULTS}

Table 1 : Distribution of the study groups $(n=100)$.

\begin{tabular}{lcc} 
Study Groups & Frequency & Percentage (\%) \\
Group A & & \\
(Overweight \& Obese Children) & 50 & 50.0 \\
Group B & & \\
(Normal Control) & 50 & 50.0 \\
Total & 100 & 100.0 \\
\hline
\end{tabular}

Table demonstrates that one hundred (100) subjects were included in this study. Of them fifty (50) were cases (Group A) and fifty were controls (Group B).
Table 2 : Distribution of fasting serum insulin level among the study groups (With $\mathrm{t}$ - test significance).

\begin{tabular}{llrrrl} 
& Study Group & \multicolumn{1}{c}{ N } & Mean & \pm SD & Range \\
Serum & Group A & 50 & 20.21 & 11.28 & $6.10-55.50$ \\
Fasting Insulin & Group B & 50 & 10.35 & 4.56 & $5.13-34.90$ \\
$(\mu \mathrm{IU} / \mathrm{L})$ & TOTAL & 100 & 15.28 & 9.89 & $5.13-55.50$
\end{tabular}

$\mathrm{t}$ value $=$ 5.732. p 0.001. Highly Significant.

Table shows that mean fasting insulin level is significantly higher in cases than that in controls $(20.21 \pm 11.28$ vs $10.35 \pm$ 4.56, $\mathrm{p}<0.001)$.

Table 3 : Distribution of HOMA-IR value among the study groups (with $\mathrm{t}$ - test significance)

\begin{tabular}{llrccc} 
& Study Group & N & Mean & \pm SD & Range \\
HOMA-IR & Group A & 50 & 4.50 & 1.95 & $1.38-8.40$ \\
Value & Group B & 50 & 2.47 & 1.11 & $1.20-8.33$ \\
& TOTAL & 100 & 3.49 & 1.88 & $1.20-8.40$ \\
\hline
\end{tabular}

$\mathrm{t}$ value $=6.392 . \mathrm{p}<0.001$. Highly Significant.

Table shows that mean HOMA-IR value is significantly higher in cases than that in controls $(4.50 \pm 1.95$ vs $2.47 \pm 1.11, \mathrm{p}<0.001)$.

Table 4 : Table Distribution of insulin resistance status among the study groups (With Chi square test significance).

\begin{tabular}{lrrrrrr} 
& \multicolumn{3}{c}{ Study Groups } & \multicolumn{2}{l}{ Total } \\
$\begin{array}{lrrrrr}\text { Insulin Resistance } \\
\text { Status }\end{array}$ & Group A & \multicolumn{2}{l}{ Group B } & & \\
& & & & & & \\
& n & $\%$ & n & $\%$ & N & $\%$ \\
Present & 42 & 84.0 & 14 & 28.0 & 56 & 56.0 \\
Absent & 08 & 16.0 & 36 & 72.0 & 44 & 44.0 \\
Total & 50 & 100.0 & 50 & 100.0 & 100 & 100.0 \\
\hline
\end{tabular}

$\chi^{2}$ value $=20.543 . p=0.000$. Highly Significant.

It is observed that $84 \%$ cases (n- 42$)$ and $28 \%$ controls (n-14) are identified with insulin resistance status. Insulin resistance status is significantly higher in cases than that in controls.

Table 5 : Distribution of metabolic syndrome status among the cases according to NCEP ATP III criteria of metabolic syndrome.

\begin{tabular}{|c|c|c|c|c|c|c|}
\hline CRITERIA & $\begin{array}{l}\text { Metabolic } \\
\text { Syndrome } \\
\text { Status }\end{array}$ & $\mathbf{N}$ & Mean & $\pm \mathrm{SD}$ & Range & Sign. \\
\hline $\begin{array}{l}\text { BMI } \\
(\mathrm{Kg} / \mathrm{m} 2)\end{array}$ & $\begin{array}{l}\text { Present } \\
\text { Absent }\end{array}$ & $\begin{array}{l}09 \\
41\end{array}$ & $\begin{array}{l}36.15 \\
30.18\end{array}$ & $\begin{array}{l}5.45 \\
4.30\end{array}$ & $\begin{array}{l}30.34-44.50 \\
25.10-44.44\end{array}$ & $\begin{array}{l}\mathrm{p}<0.001 \\
\text { Highly } \\
\text { Significant }\end{array}$ \\
\hline $\begin{array}{l}\text { Serum TG } \\
(\mathrm{mg} / \mathrm{dl})\end{array}$ & $\begin{array}{l}\text { Present } \\
\text { Absent }\end{array}$ & $\begin{array}{l}09 \\
41\end{array}$ & $\begin{array}{l}177.67 \\
104.83\end{array}$ & $\begin{array}{l}24.05 \\
19.14\end{array}$ & $\begin{array}{r}150-218 \\
71-148\end{array}$ & $\begin{array}{l}\mathrm{p}<0.001 \\
\text { Highly } \\
\text { Significant }\end{array}$ \\
\hline $\begin{array}{l}\text { Serum HDL } \\
\text { Cholesterol } \\
(\mathrm{mg} / \mathrm{dl})\end{array}$ & Present & 09 & 36.44 & 3.39 & $\begin{array}{l}32-42 \\
31-43\end{array}$ & $\begin{array}{l}\mathrm{p}>0.05 \\
\text { Not } \\
\text { Significant }\end{array}$ \\
\hline $\begin{array}{l}\text { Serum } \\
\text { Fasting Insulin } \\
(\mu \mathrm{IU} / \mathrm{L})\end{array}$ & $\begin{array}{l}\text { Present } \\
\text { Absent }\end{array}$ & 09 & 33.93 & 12.90 & $21.00-55.50$ & $\begin{array}{l}\mathrm{p}<0.001 \\
\text { Highly } \\
\text { Significant }\end{array}$ \\
\hline
\end{tabular}

Volume 15, Issue 2, July 2016 
Table 6 : Distribution of serum lipid profiles according to metabolic syndrome status of the study group $(n=100)$ (With $\mathrm{t}$ - test significance).

\begin{tabular}{|c|c|c|c|c|c|c|}
\hline & $\begin{array}{l}\text { Metabolic } \\
\text { Syndrome } \\
\text { Status }\end{array}$ & $\mathbf{N}$ & Mean & \pm SD & Range & Sign. \\
\hline $\begin{array}{l}\text { Serum Total } \\
\text { Cholesterol } \\
(\mathrm{mg} / \mathrm{dl})\end{array}$ & Present & 10 & 167.00 & 43.92 & $103-243$ & $\begin{array}{l}\mathrm{p}=0.001 \\
\text { Highly } \\
\text { Significant }\end{array}$ \\
\hline $\begin{array}{l}\text { Serum LDL } \\
\text { Cholesterol } \\
(\mathrm{mg} / \mathrm{dl})\end{array}$ & Absent & 10 & 103.50 & 27.14 & $59-109$ & $\begin{array}{l}\mathrm{p}=0.007 \\
\text { Highly } \\
\text { Significant }\end{array}$ \\
\hline $\begin{array}{l}\text { Serum HDL } \\
\text { Cholesterol } \\
(\mathrm{mg} / \mathrm{dl})\end{array}$ & Present & 10 & 37.00 & 3.65 & $32-42$ & $p=0.013$ \\
\hline $\begin{array}{l}\text { Serum TG } \\
(\mathrm{mg} / \mathrm{dl})\end{array}$ & $\begin{array}{l}\text { Present } \\
\text { Absent }\end{array}$ & $\begin{array}{l}10 \\
90\end{array}$ & $\begin{array}{r}175.50 \\
97.09\end{array}$ & $\begin{array}{l}23.68 \\
18.54\end{array}$ & $\begin{array}{r}150-218 \\
65-150\end{array}$ & $\begin{array}{l}\mathrm{p}=0.000 \\
\text { Highly } \\
\text { Significant }\end{array}$ \\
\hline
\end{tabular}

Table shows that mean serum total cholesterol, LDL cholesterol and TG levels are significantly higher among metabolic syndrome group than non-metabolic syndrome group (167 \pm 43.92 vs $130.56 \pm 32.09,103.50 \pm 27.14$ vs $74.03 \pm 10.28$ and $175 \pm 23.68$ vs $97.09 \pm 18.54) \mathrm{mg} / \mathrm{dl}$. Serum HDL cholesterol is significantly lower among metabolic syndrome group than non-metabolic syndrome group $(37 \pm 3.65$ vs $40.28 \pm 4.26$ $\mathrm{mg} / \mathrm{dl})$.

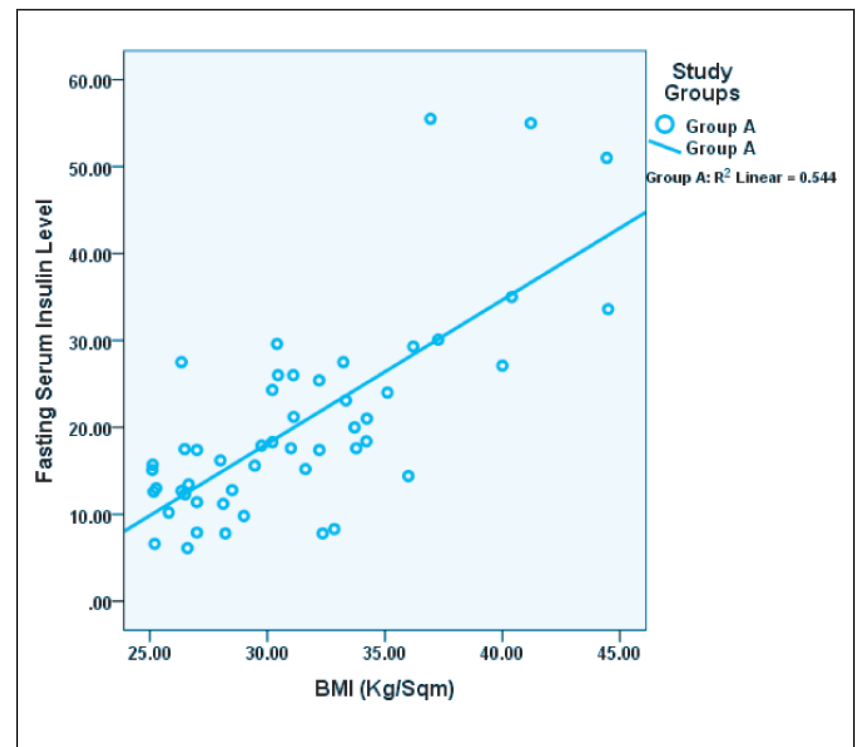

Figure 1 : Scatter diagram showing positive correlation between BMI and fasting serum insulin level.

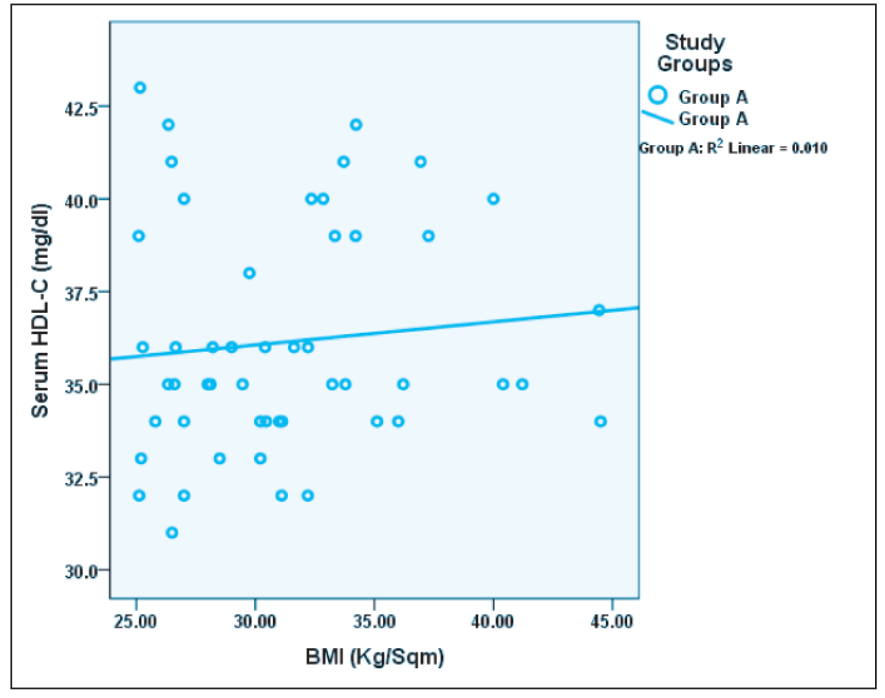

Figure 2 : Scatter diagram showing correlation between BMI and fasting serum HDL level.

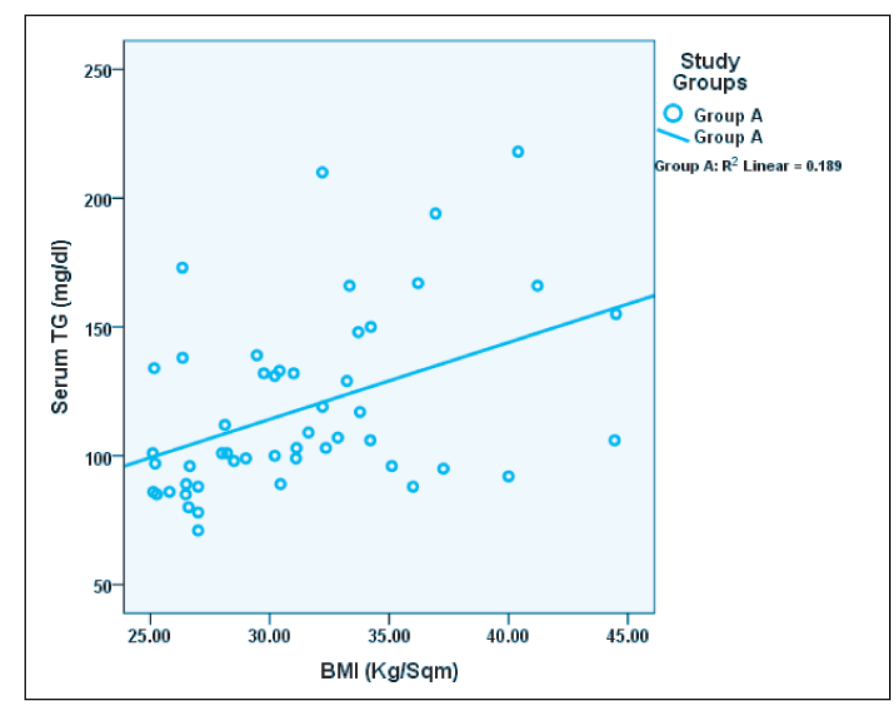

Figure 3 : Scatter diagram showing positive correlation between BMI and fasting serum TG level.

\section{DISCUSSION}

Fasting serum insulin level among the study groups were statistically analyzed and observed to possess significant increased values in serum who were overweight and obese school children. On the other hand it is observed that $84 \%$ cases (n-42) were identified with insulin resistance status (HOMA-IR $>2.5$ ). Insulin resistance in this study is well defined in the cases and found to be associated with increased body weight (BMI). Mean HOMA-IR is 6.92 in metabolic syndrome group and 3.11 in without metabolic syndrome group in cases of group A. By using HOMA-IR cutoff value, insulin resistance was found in $84 \%$ of overweight and obese children (Mean 
HOMA value is 4.50). Insulin resistance was higher in subjects with metabolic syndrome compared to those without metabolic syndrome. The prevalence of insulin resistance in children with metabolic syndrome was $65.2 \%$ in a study in Beijing 9 . In a study in south India, $69 \%$ of obese and overweight children where identified with insulin resistance ${ }^{10}$. So results observed were consistent with that of such studies.

\section{CONCLUSION}

We found that insulin resistance was strongly associated with metabolic syndrome and its components. Therefore the high prevalence of metabolic syndrome as observed in overweight children of this study shows the importance of action planning in health and relevant sectors for prevention and treatment of obesity beginning in the early stages of life.

\section{DISCLOSURE}

The authors declared no competing interest.

\section{REFERENCES}

1. The world health report 1998. Life in the 21st century: A vision for all. Geneva, World Health Organization. 1998.

2. Mohammed Q, Mitchell AL. Mechanisms of obesity associated insulin resistance: Many choices on the menu. Gene \& Development. 2007;21:1443-1455.

3. Kaplan NM. The deadly quartet: Upper body obesity, glucose intolerance, hypertriglyceridemia and hypertension. Arch Intern Med.1989;149(7):1514-1520.

4. Canete R, Gil Campos M, Aguilera CM et al. Development of insulin resistance and its relation to diet in the obese child. Eur J Nutr. 2007;46:181-187.

5. Zannolli R, Rebeggiani A, Chiarelli F, Morgese G. Hyperinsulinism as a marker in obese children. Am J Dis Child.1993;147:837-841.

6. Stern M, Williams K, Gonzalez-Villalpando C et al. Does the metabolic syndrome improve identification of individuals at risk of type 2 diabetes and/or cardiovascular disease? Diabetes Care. 2004;27(11):2676-2681.

7. Friedewald WT, Levy RI, Fredrickson DS. Estimation of the concentration of low-density lipoprotein cholesterol in plasma, without use of the preparative ultracentrifuge. Clin Chem. 1972;18:499-502.

8. Tresaco B, Bueno G, Pineda I, Moreno LA, Garagorri JM, Bueno M. Homeostatic Model Assessment (HOMA) index cut-off values to identify the metabolic syndrome in children. J Physiol Biochem. 2005;61(2):381-368.

9. Gurumurthy P, Gururajan P, Sarasa B A, Kirthivasan V, Saibabu R et al. Comparison between serum insulin levels and its resistance with biochemical, clinical and anthropometric parameters in south Indian children and adolescents. Ind J Clin Biochem. 2011;26(1):22-27.

10. Wan NJ, Mi J, Wang TY et al. Metabolic syndrome in overweight and obese school children in Beijing. Zhonghua Er Ke Za Zhi. 2007; 45(6):417-421. 